\title{
Paleomagnetic results from the Silurian of the Yangtze paraplatform
}

\author{
NEIL D. OPDYKE ${ }^{1}$, K. HUANG ${ }^{2}$, G. XU ${ }^{2}$, W.Y. ZHANG ${ }^{2}$ and D.V. KENT ${ }^{3}$ \\ ${ }^{\prime}$ Department of Geology, University of Florida, Gainesville, FL 32166 (U.S.A.) \\ ${ }^{2}$ Institute of Geology, Academia Sinica, Beijing (P.R. of China) \\ ${ }^{3}$ Department of Geological Sciences, Columbia University, Lamont-Doherty Geological Observatory, Palisades, NY 10964 (U.S.A.)
}

(Received February 3, 1986; revised version accepted May 8, 1986)

\begin{abstract}
Opdyke, N.D., Huang, K., Xu, G., Zhang, W.Y. and Kent, D.V., 1987. Paleomagnetic results from the Silurian of the Yangtze paraplatform. In: D.V. Kent and M. Krs (Editors), Laurasian Paleomagnetism and Tectonics. Tectonophysics, 139: 123-132.

Samples have been collected from sites from three localities located in Sichuan, and in Yunnan provinces. The samples were taken from limestones and red siltstones covering most of the Silurian of the South China Block. The results from the limestone sites were disappointing and all the sites that yielded successful results were from red siltstones. Characteristic high temperature components were successfully isolated from fifteen of these sites. The sites from Xiushan County, Sichuan $\left(28.48^{\circ} \mathrm{N}, 108.99^{\circ} \mathrm{E}\right)$, successfully pass the fold test at the $99 \%$ level indicating that the magnetization was acquired before folding in the Mesozoic. The direction obtained from this locality is directed toward the east with shallow positive inclinations $\left(D=85.6^{\circ}, I=12.1^{\circ}, \alpha_{95}=5.33^{\circ}\right)$; the results obtained from a single red bed locality from Qijiang County, Sichuan $\left(28.58^{\circ} \mathrm{N}, 106.85^{\circ} \mathrm{E}\right)$, yield a similar direction.

The results from the upper Silurian of Yunnan $\left(25.5^{\circ} \mathrm{N}, 103.73^{\circ} \mathrm{E}\right)$ were obtained from only two sites and the isolated directions were towards the west with shallow inclinations. This direction is opposed to the characteristic directions obtained from Sichuan and are interpreted as a reversed Silurian direction. The paleomagnetic pole position determined from all sites given equal weight $(N=15)$ falls at $4.9^{\circ} \mathrm{N}$ lat., $194.7^{\circ} \mathrm{E}$ long. with $\alpha_{95}=5.61^{\circ}$.
\end{abstract}

\section{Introduction}

Asia is now known to consist of a collage of plates both major and minor which coalesced during the Paleozoic and Mesozoic to form a new continental area. The resulting tectonic history has elicited a great deal of interest from the earth-science community. In order to understand the geologic history of the region, it is important to have reliable paleomagnetic polar wandering curves from the major continental fragments. Two of the most important of these are the Sino-Korean Craton and Yangtze Craton (Zhang et al., 1984). The purpose of the study undertaken here is to produce a reliable paleomagnetic pole position from the Silurian of the Yangtze Craton, which will hopefully eventually aid in the understanding of the geologic history of the region.

In the western part of the Yangtze Craton or South China Block, the Silurian system is widely distributed, with well understood stratigraphy and good faunal control ( $\mathrm{Yu}$ et al., 1984). For these reasons it was proposed that the Yangtze platform would be an ideal region for the subdivision of the Silurian system and the establishment of stages in China. Lin et al. (1982), in fact, suggested that the Guanyinqiao section in Qijiang county of Sichuan Province be the strato-type section for the Longmaxian and Shiniulanian stages of the Lower Silurian, the Rongxi section in Xiushan county of Sichuan province for the Baishaan Stage of the Lower Silurian and the Xiushan Stage of the Mid- 
STRATIGRAPHIC CORRELATION

SONGKAN SECTION

RONGXI SECTION

HONGMIAO SECTION

TONGZI, GUIZHOU

XIUSHAN, SICHUAN

QUJING, YUNNAN

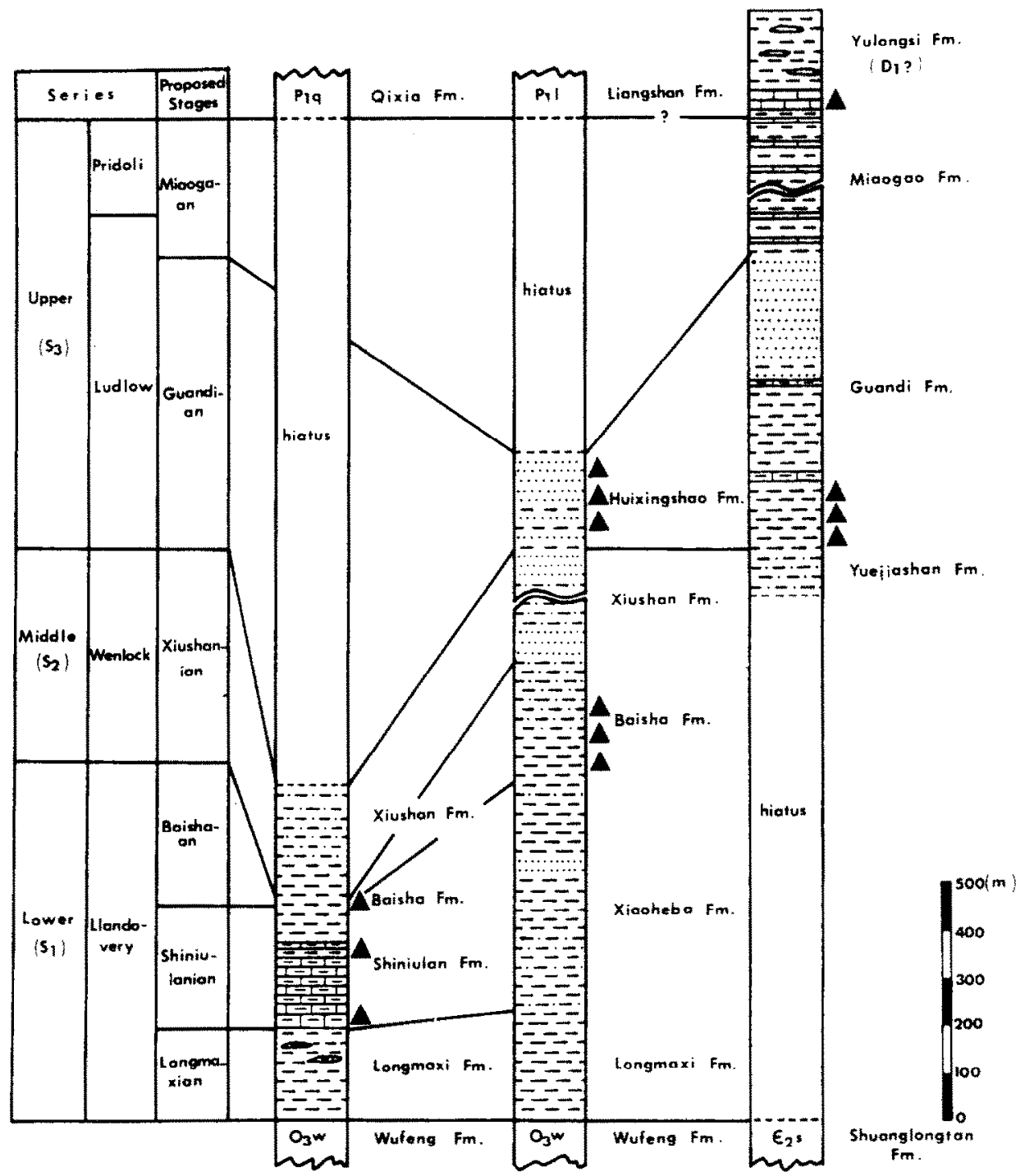

Fig. 1. Stratigraphic sections from the three areas sampled. Stratigraphic position of the sampled interval are indicated by triangles.

dle Silurian, and the Hongmiao section in Qujing county of Yunnan province for the Guandian and Miaogaoan stages of the Upper Silurian. Our samples were collected from the above sections (Fig. $1)$.

The Songkan section is at the northwestern limb of a NNE-SSW trending anticline which is located in the border area between Sichuan pro- vince and Guizhou province. The Longmaxi Formation of the lower Silurian is exposed on both limbs, conformably overlying the Ordovician. It is mainly composed of black and greyish-black shales yielding abundant graptolites, whereas the overlying Shiniulan Formation, $264-357 \mathrm{~m}$ in thickness, consists of dark-grey thin-bedded argillaceous limestones interbedded with sandy shales in the 
middle part, and greyish-green sandstones and shales in the upper part. The overlying Baisha Formation is characterized by purplish-red shales and is only $8 \mathrm{~m}$ in thickness on both limbs. The Xiushan Formation of the Middle Silurian, which is disconformably overlain by the Permian, is composed of yellowish-green silty shales with sandstone interbeds, and reddish bioclastic limestone lenses at the base. The bedding at the northwestern limb of the anticline dips at $30^{\circ}-35^{\circ} \mathrm{W}$ while the bedding on the southeastern limb dips at $60^{\circ}-65^{\circ} \mathrm{E}$. Altogether eight sites were drilled from the two limbs, five from the limestones of the Shiniulan Formation, two from the bioclastic limestones of the Xiushan Formation and only one from the red shales of the Baisha Formation owing to the difficulty in sampling.

The Rongxi section is exposed on both limbs of a syncline whose axis runs NNE-SSW. The northwestern limb dips at $46^{\circ}-67^{\circ} \mathrm{E}$ whereas the southeastern dips at $36^{\circ}-48^{\circ} \mathrm{W}$. The Lower Silurian Longmaxi Formation and the Xiaoheba Formation (Shiniulanian Stage) are of similar lithology and thickness to that of their equivalents at the Guanyinqiao section. The overlying Baisha Formation and Xiushan Formation, however, are much thicker than their counterparts at the Guanyinqiao section. The Baisha Forma-

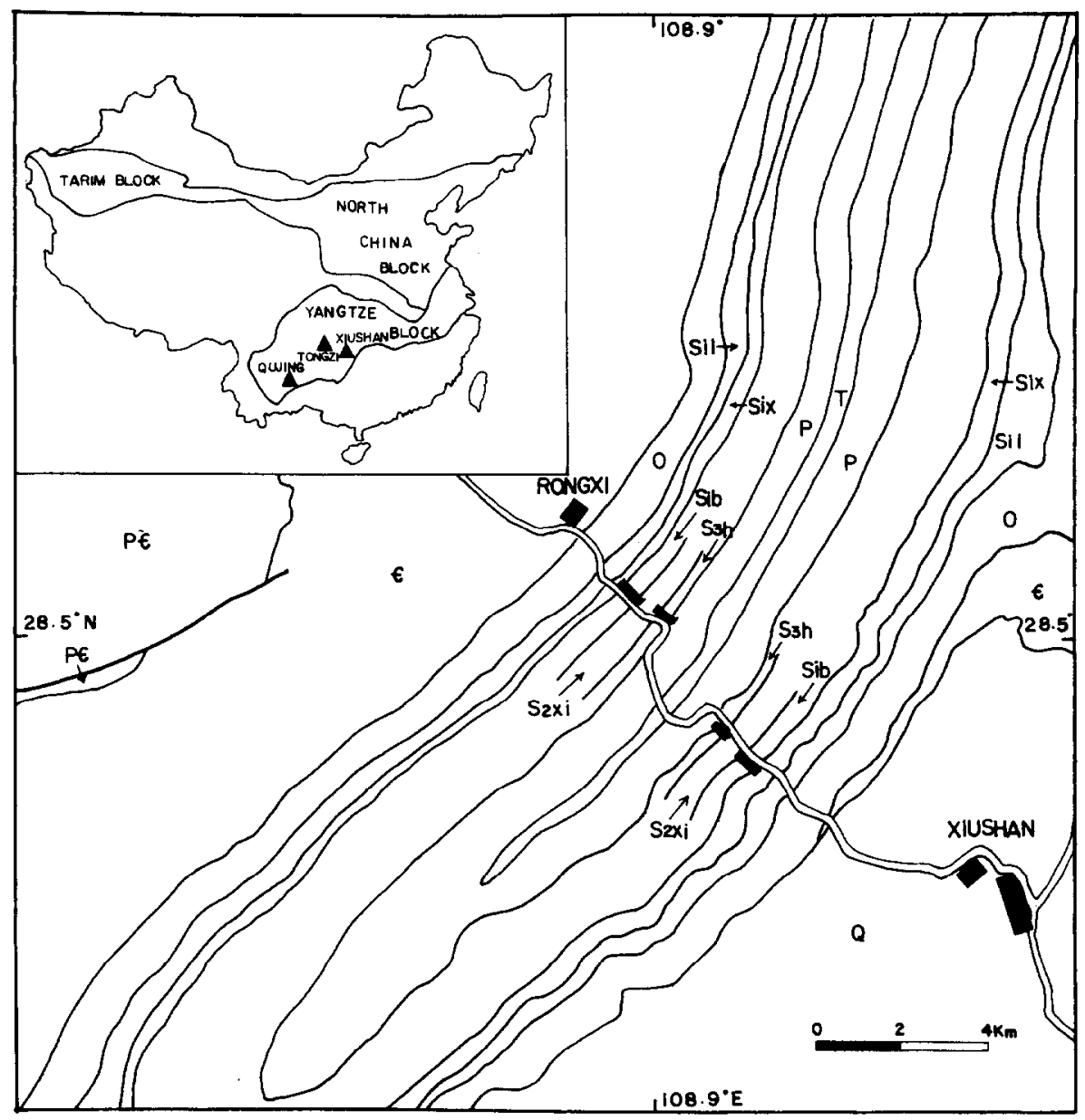

Fig. 2. Geological sketch map of the sample locality in Xiushan County, southeast Sichuan. PE-Precambrian, E-Cambrian, $O$-Ordovician, S11-Lower Silurian Longmaxi Formation, SIx-Lower Silurian Xiaoheba Formation, S1b-Lower Silurian Baisha Formation, $S 2 x i-$ Middle Silurian Xiushan Formation, $S 3 h-$ Upper Silurian Huixingshao Formation, $P-P e r m i a n, T-T r i-$ assic. The bars indicate the sampled sections and the triangles in the insert indicate the sampling localities studied. 
tion, $256 \mathrm{~m}$ in thickness, consists mainly of red, purplish-red and greyish-green sparcely fossiliferous silty shales and siltstones. The middle Silurian Xiushan Formation at this section is $587 \mathrm{~m}$ thick and yields trilobites, brachiopods and gastropods. The lower part of the unit consists of yellowish and greyish-green fine-grained quartz-sandstones occasionally intercalated with sandy limestones, and the upper part is made up of greyish-green calcareous shales and sandstones containing calcareous nodules. Overlying is the Huixingshao Formation (Guandian Stage, Middle Silurian) which is $198 \mathrm{~m}$ in thickness, composed mainly of purplish-red and greyish-green siltstones and silty shales, and is in turn disconformably overlain by the Permian. Seventeen sites were drilled in the redbeds (Baisha Formation and Huixingshao Formation) from the two limbs (Fig. 2).

The Qujing district of Yunnan is the only area on the Yangtze Platform where the stratigraphic section extends from the Silurian into the Devonian without major interruption. The structure of the Hongmiao section is a monocline dipping northeast at $25^{\circ}-45^{\circ}$. The Guandi Formation, $609 \mathrm{~m}$ in thickness, consists of purplish-red to dark purple siltstones and silty shales intercalated with yellow to yellowish-green marlites and nodular marlites, yielding cephalopods, brachiopods, corals and conodonts. The Miaogao Formation is $944 \mathrm{~m}$ thick and chiefly composed of dark grey to greyish-black nodular limestones intercalated with yellowish shales and argillaceous siltstones, containing abundant shelly facies fossils such as brachiopods, cephalopods and conodonts. Whether the overlying Yulongsi Formation, which consists of greyish-black calcareous shales interbedded with nodular limestones, should be assigned into the Upper Silurian or the Lower Devonian has not been resolved ( $\mathrm{Lin}$ et al., 1982; $\mathrm{Mu}$ et al., 1982). Ten sites were drilled in the redbeds of the Guandi Formation and five sites in the nodular limestones near the base of the Yulongsi Formation.

\section{Sampling}

Five or more cores, $2.5 \mathrm{~cm}$ in diameter, were drilled at each site from an individual bed $1 \mathrm{~m}$ or less in thickness. The sites were situated where possible in road cuts or stream beds. Each individual core was oriented in situ using a Brunton Compass and an inclinometer and the dip and strike of the formation at each sampling site was recorded. The corcs were returned to the U.S. where they were sliced into cylinders $2.5 \mathrm{~cm}$ in length.

All samples were then measured on a cryogenic magnetometer. Samples were progressively demagnetized utilizing commercially available thermal and alternating field (a.f.) demagnetization equipment.

\section{The Xiushan Section}

The direction of the NRM of the samples from this section are grouped in the northeast quadrant with both positive and negative inclinations, with some stringing toward the present earth field. When a tilt correction is applicd, a prominent grouping is seen and shallow angles directed toward the East. Partial thermal demagnetization was then performed on one sample from each site in increments of $100^{\circ}$ to $400^{\circ} \mathrm{C}, 50^{\circ} \mathrm{C}$ increments to $600^{\circ} \mathrm{C}$, then at $625^{\circ}, 650^{\circ}, 660^{\circ}, 670^{\circ}$ and $680^{\circ}$. Figure 3 illustrates the response to thermal demagnetization of samples taken from NW (a) and SE (b) limbs of the syncline, this type of behavior is observed in nine of the sites. The blocking temperatures are spread over the entire demagnetization temperature spectrum and the decay of the magnetization is essentially linear to the origin except for a small low temperature component in the direction of the present earth's field which is removed in low temperatures. The samples that are illustrated in Fig. 3a, b are from opposite flanks of the syncline and have been corrected for tilt; the directions after tilt correction are similar.

The behavior described above is typical. However, some of the sites had a significant overprint in the present direction of the earth's magnetic field probably due to in-site weathering. Figure $3 \mathrm{c}$ illustrates the behavior of one such site which is located on the southeastern limb of the syncline. The characteristic direction is not resolved until demagnetization temperatures in excess of $650^{\circ} \mathrm{C}$ 


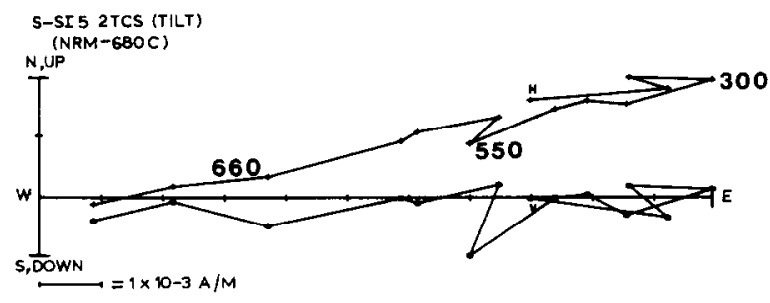

(a)
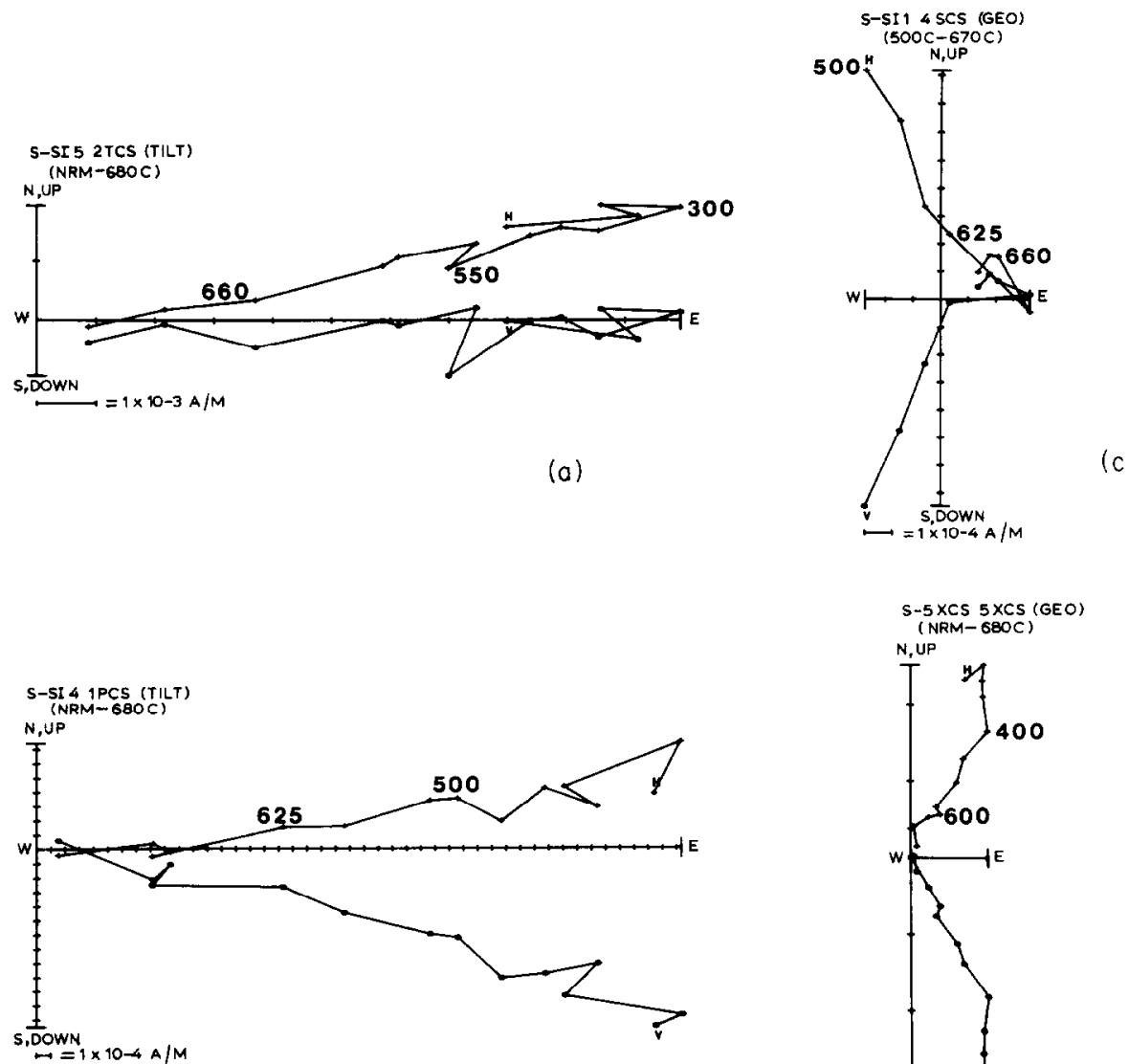

(b)

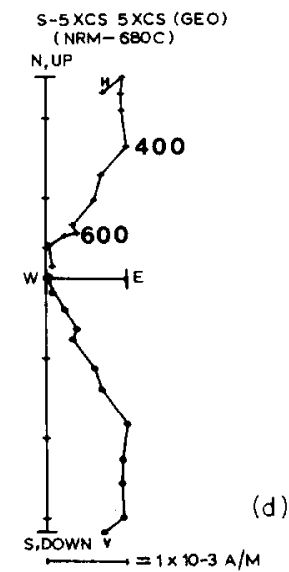

Fig. 3. Orthogonal projections of four samples from the Xiushan section, corrected for bedding tilt.

are reached. The characteristic direction remaining in the high temperature component appears to be the same as that illustrated in Fig. 3A and B. The remaining three sites (Fig. 3d, e, f) appears to be entirely overprinted and yield univectorial results which are close to the direction of the earth's dipole field in present coordinates.

As a result of the information obtained from the pilot studies, samples from all sites were demagnetized in at least three steps of $450^{\circ}, 500^{\circ}$, $550^{\circ} \mathrm{C}$. If these points were not linear and toward origin, then the demagnetization proceeded to higher temperatures and in the case of the site illustrated in Fig. 3c, samples were taken to temperatures up to $670^{\circ} \mathrm{C}$. The direction for each sample was then determined using the principal component method (Kirschvink, 1980). These vectors were then combined using Fisher (1953) statics.
Figure 4 shows the site mean directions before and after correcting for bedding tilt. Before correcting for bedding tilt, there are three distinct groups (Fig. 4A). The largest group has directions towards the east-northeast with positive inclinations of about $50^{\circ}$. Four site mean directions have similar declinations but with negative inclinations. Three sites are directed towards the north with inclinations from $40^{\circ}$ to $60^{\circ}$ near the present dipole field.

Figure 4B shows the site mean directions after correction for bedding. The sites with ENE declinations and positive and negative inclinations before tilt correction coalesce into a well defined group with a shallow positive inclination directed almost due east. This group passes the fold test at the 99\% level (McElhinny, 1964) and therefore acquired their characteristic direction before folding. The three sites which were closest to the 

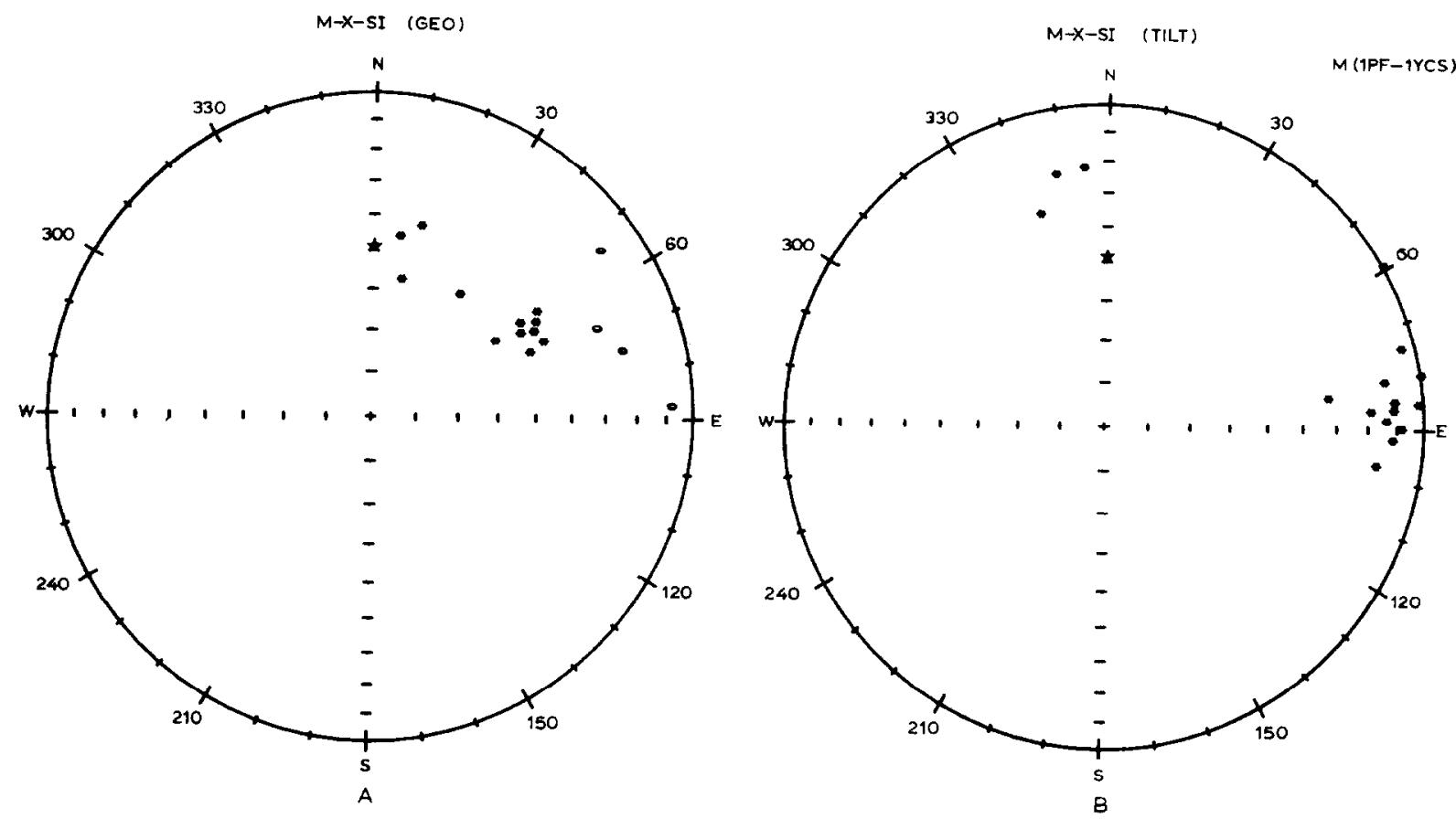

Fig. 4. Site mean directions from Xiushan section before (left) and after (right) tilt correction, stars (open circles) represent directions on the lower (upper) hemisphere. Large star represents dipole field direction.

recent field direction before unfolding clearly do not pass the fold test and are not considered further in the analysis. The paleomagnetic pole position $(N=12)$ calculated from the tilt corrected site mean direction falls at $6.8^{\circ} \mathrm{N}$ lat. and $195.7^{\circ} \mathrm{E}$ long.

\section{Results for Qijiang County, Sichuan}

Figure 5 gives the directions of NRM from all the samples of Silurian age collected from the Tongzi section. The directions of magnetization in the present coordinate system are strung between the present dipole field direction and a direction which is more steeply inclined toward the northeast. After correction for tilt (Fig. 5B) the data separate into two groups indicating that the NRM direction is dominated by a post folding component.

Pilot thermal demagnetization curves were obtained from all sites as previously described. Those illustrated (Fig. 6) show the behavior of samples from a limestone site (Fig. 6b) and one from the single site that was drilled in the red shale unit (Fig. 6a). The sample from the limestone sites yields a direction which is essentially directed along the present dipole field and which fails the fold test. The orthogonal plot from the red siltstone, however, reveals a component that is essentially univectorial to temperatures above $600^{\circ} \mathrm{C}$, however, above $650^{\circ} \mathrm{C}$, the direction trends slightly more toward the east.

Since red siltstone sites were not available from both limbs of the structure, a fold test could not be applied. However, the direction from the red siltstone was regarded as reliable and used in the final analysis.

\section{Results from the Qujing District of Yunnan}

The directions of the NRM from the Qujing district yield directions with northerly declinations and positive inclinations uncorrected for tilt which are close to the present dipole field direction at the locality. Pilot samples from each site were selected for thermal demagnetization studies. Samples from the limestone sites were also partially demagnetized using a.f. demagnetization.

The results in most cases were disappointing due to what is interpreted to be a strong overprint 

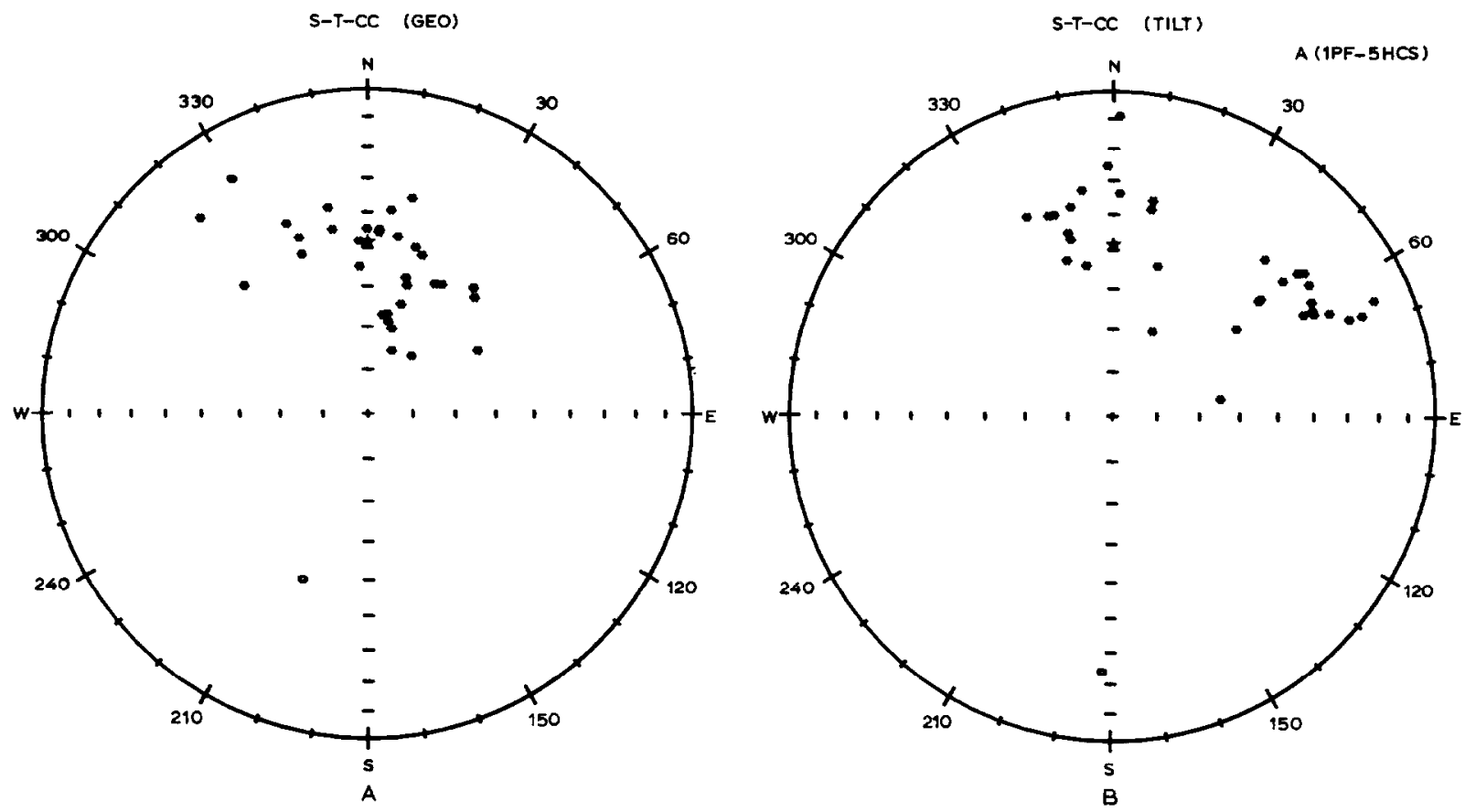

Fig. 5. Directions of NRM from the Tongzi section before (left) and after (right) correcting for bedding (symbols as in Fig. 4).

in the present field direction probably resulting from weathering. Figure 7a demonstrates the typical behavior for these samples.

Fortunately, two of the sites responded in a different manner. Figure $7 b$ is a representative demagnetization diagram of these two sites. It is clear that a large secondary component is removed in temperatures up to $650^{\circ} \mathrm{C}$. Above this temperature, a characteristic direction is isolated. The high temperature portion of this data set (above
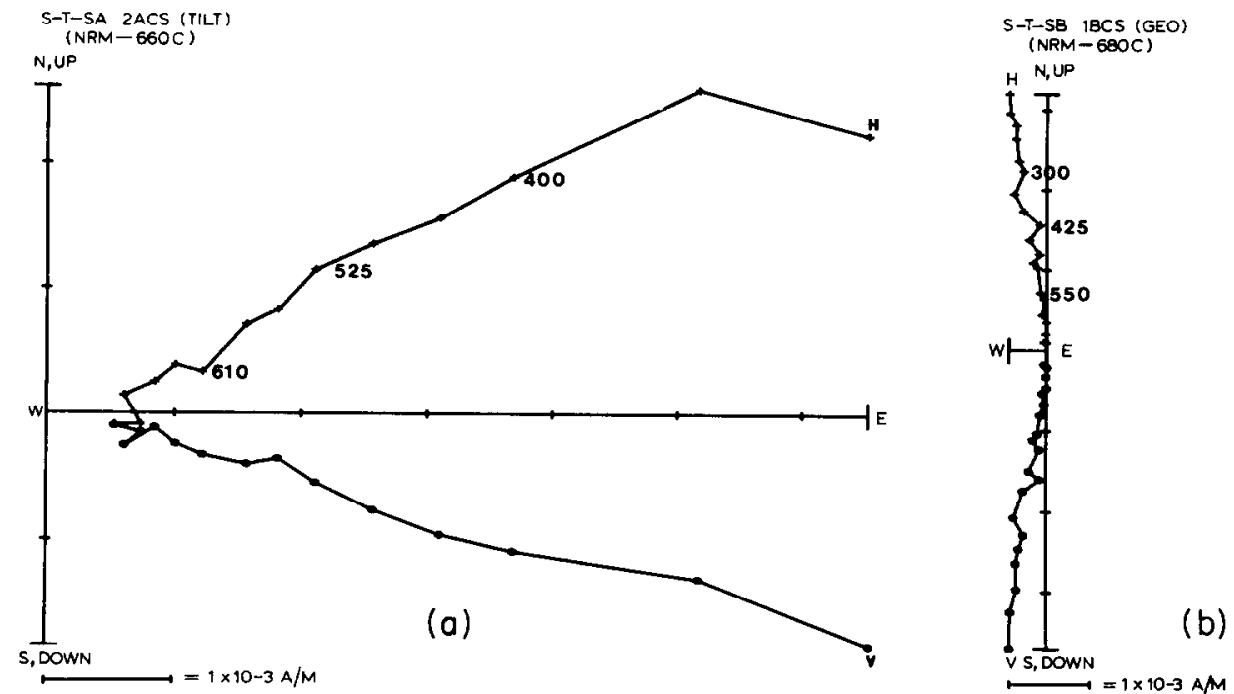

Fig. 6. Orthogonal demagnetization plots of two samples from Tongzi section. The plot on the left is from red siltstone corrected for bedding tilt. The one on the right is from a limestone uncorrected for tilt. 
TABLE 1

Silurian site statistics

\begin{tabular}{|c|c|c|c|c|c|c|c|c|c|c|}
\hline \multirow[t]{2}{*}{$\overline{\text { Site }}$} & \multirow[t]{2}{*}{$N$} & \multirow[t]{2}{*}{$D^{\circ}$} & \multirow[t]{2}{*}{$I^{\circ}$} & \multirow[t]{2}{*}{$D c$} & \multirow[t]{2}{*}{ Ic } & \multirow[t]{2}{*}{$\alpha_{95}$} & \multirow[t]{2}{*}{$K$} & \multirow{2}{*}{$\begin{array}{l}\text { Temp. } \\
\text { range }\left({ }^{\circ} \mathrm{C}\right)\end{array}$} & \multicolumn{2}{|c|}{ Pole position } \\
\hline & & & & & & & & & ${ }^{\circ}$ lat. & ${ }^{\circ}$ long. \\
\hline \multicolumn{11}{|c|}{ Tongzi, N. Guizhou $\left(28.58^{\circ} \mathrm{N}, 106.85^{\circ} \mathrm{E}\right)$} \\
\hline A & 5 & 20.1 & 59.9 & 70.1 & 20.1 & 8.4 & 84.0 & $600-660$ & 22.39 & 197.00 \\
\hline $\mathrm{B}^{*}$ & 5 & 358.9 & 50.7 & 56.9 & 29.3 & 11.2 & 47.5 & $450-640$ & 36.20 & 197.83 \\
\hline$C *$ & 5 & 31.7 & 69.4 & 351.8 & 48.5 & 9.4 & 67.7 & $400-550$ & 82.81 & 26.23 \\
\hline$D^{*}$ & 4 & 23.5 & 51.6 & 359.0 & 29.2 & 19.0 & 24.4 & $350-400$ & 77.00 & 291.27 \\
\hline$E^{*}$ & 5 & 22.1 & 56.7 & 354.7 & 32.8 & 9.4 & 67.7 & $350-400$ & 78.22 & 312.51 \\
\hline$F^{*}$ & 5 & 333.4 & 26.9 & 36.7 & 55.5 & 30.8 & 7.1 & $300-400$ & 58.34 & 173.66 \\
\hline$G^{*}$ & 4 & 4.3 & 44.0 & 62.8 & 31.6 & 3.4 & 722.0 & $350-400$ & 31.60 & 193.53 \\
\hline $\mathrm{H}^{*}$ & 5 & 356.5 & 45.7 & 57.2 & 31.0 & 12.6 & 37.9 & $300-400$ & 36.42 & 196.55 \\
\hline \multicolumn{11}{|c|}{ Xiushan, $S E$ Sichwan $\left(28.48^{\circ} \mathrm{N}, 108.99^{\circ} \mathrm{E}\right)$} \\
\hline $1 *$ & 2 & 33.9 & 52.2 & 91.6 & 45.0 & 29.8 & 72.4 & $450-650$ & 11.01 & 174.50 \\
\hline $\mathrm{J}$ & 4 & 35.4 & 52.5 & 86.1 & 18.6 & 4.5 & 414.6 & $450-550$ & 7.96 & 192.35 \\
\hline $\mathbf{K}$ & 5 & 57.3 & 45.7 & 85.3 & 2.7 & 5.2 & 218.4 & $450-550$ & 4.74 & 199.97 \\
\hline $\mathbf{L}$ & 4 & 57.1 & 40.2 & 86.1 & 11.2 & 5.4 & 294.7 & $450-550$ & 6.09 & 195.75 \\
\hline $\mathbf{M}$ & 5 & 61.9 & 43.6 & 89.8 & 8.7 & 2.0 & 1433.1 & $450-600$ & 2.30 & 195.18 \\
\hline $\mathbf{N}$ & 4 & 58.3 & 53.9 & 97.5 & 16.1 & 5.2 & 319.4 & $450-550$ & -2.59 & 188.11 \\
\hline $\mathrm{O}$ & 4 & 60.3 & 47.0 & 92.1 & 11.6 & 4.9 & 351.9 & $500-600$ & 0.96 & 192.80 \\
\hline $\mathbf{P}$ & 5 & 67.7 & 46.9 & 88.2 & 13.7 & 5.2 & 219.2 & $450-550$ & 4.8 & 193.7 \\
\hline$Q$ & 5 & 66.1 & 42.4 & 84.5 & 10.7 & 6.9 & 125.2 & $450-550$ & 7.4 & 196.8 \\
\hline $\mathrm{R}$ & 5 & 59.6 & 41.9 & 80.3 & 13.4 & 5.5 & 193.4 & $450-550$ & 11.7 & 197.5 \\
\hline $\mathrm{S}$ & 4 & 87.5 & -8.3 & 82.1 & 31.0 & 12.3 & 57.2 & $660-670$ & 14.6 & 187.6 \\
\hline $\mathrm{T}$ & 5 & 74.9 & -21.6 & 801 & 0.7 & 1.8 & 1917.5 & $500-600$ & 8.9 & 203.4 \\
\hline $\mathrm{U}^{*}$ & 4 & 53.6 & -14.7 & 59.4 & 0.7 & 6.7 & 188.92 & $600-670$ & 26.8 & 214.3 \\
\hline V & 3 & 68.1 & -26.9 & 74.6 & 5.7 & 9.1 & 184.4 & $500-600$ & 14.9 & 203.8 \\
\hline $\mathrm{W}^{*}$ & 3 & 14.0 & 40.1 & 354.6 & 21.5 & 10.4 & 141.5 & $500-620$ & 72.0 & 306.1 \\
\hline$X^{*}$ & 5 & 11.8 & 55.3 & 342.4 & 32.6 & 24.5 & 10.9 & $450-550$ & 70.6 & 348.99 \\
\hline$Y^{*}$ & 4 & 8.4 & 440 & 348.2 & 18.5 & 18.5 & 25.5 & $450-650$ & 69.8 & 324.6 \\
\hline F.M. & 12 & 64.4 & 31.8 & 85.6 & 12.1 & 5.3 & 67.4 & & 6.8 & 195.7 \\
\hline \multicolumn{11}{|c|}{ Qujing, NE Yunnan $\left(25.5^{\circ} \mathrm{N}, 103.73^{\circ} \mathrm{E}\right)$} \\
\hline$A *$ & 5 & 61.3 & 55.1 & 23.8 & 40.6 & 12.6 & 37.9 & $550-670$ & 68.3 & 194.8 \\
\hline B * & 5 & 2.9 & 58.2 & 351.1 & 25.5 & 14.8 & 27.5 & $640-675$ & 75.3 & 320.2 \\
\hline$C^{*}$ & 6 & 118.9 & 39.4 & 73.9 & 52.7 & 15.9 & 18.6 & $450-550$ & 26.5 & 167.5 \\
\hline$D^{*}$ & 4 & 4.6 & 52.3 & 0.8 & 10.4 & 13.4 & 48.1 & $640-675$ & 69.7 & 281.3 \\
\hline$E^{*}$ & 5 & 295.5 & 58.3 & 325.5 & 29.7 & 27.6 & 8.7 & $640-670$ & 56.5 & 363.4 \\
\hline $\mathrm{F}$ & 5 & 282.4 & 8.7 & 283.8 & -4.4 & 11.7 & 43.9 & $640-670$ & 11.4 & 365.7 \\
\hline $\mathrm{G}$ & 5 & 279.4 & 21.5 & 289.7 & 10.9 & 9.3 & 69.3 & $640-675$ & 20.1 & 370.2 \\
\hline $\mathrm{H}^{*}$ & 5 & 359.5 & 46.9 & 359.1 & 10.9 & 7.9 & 96.0 & $600-670$ & 70.0 & 286.5 \\
\hline$I^{*}$ & 5 & 32.5 & 59.8 & 11.0 & 25.6 & 13.0 & 35.7 & $600-670$ & 74,2 & 241.1 \\
\hline$J *$ & 5 & 204.0 & 65.3 & 277.9 & 53.6 & 33.1 & 6.3 & $600-675$ & 20.2 & 42.9 \\
\hline $\mathrm{K}^{*}$ & 4 & 358.0 & 54.3 & 13.0 & 32.0 & 15.4 & 36.4 & $60-90$ & 75.4 & 225.2 \\
\hline $\mathrm{L}^{*}$ & 5 & 355.2 & 45.5 & 7.5 & 24.5 & 9.9 & 60.7 & $60-90$ & 75.5 & 253.2 \\
\hline $\mathbf{M} *$ & 5 & 38.9 & 49.7 & 38.7 & 24.7 & 24.5 & 10.7 & $60-90$ & 51.6 & 205.4 \\
\hline$N *$ & 5 & 352.5 & 46.0 & 5.2 & 25.1 & 20.9 & 14.3 & $60-90$ & 76.8 & 261.0 \\
\hline $\mathrm{O}^{*}$ & 5 & 247.4 & 49.8 & 3.3 & 30.0 & 12.2 & 40.4 & $60-90$ & 80.1 & 265.0 \\
\hline
\end{tabular}

* Not involved in the calculation of the formation mean (F.M.) or of the overall pole position. 

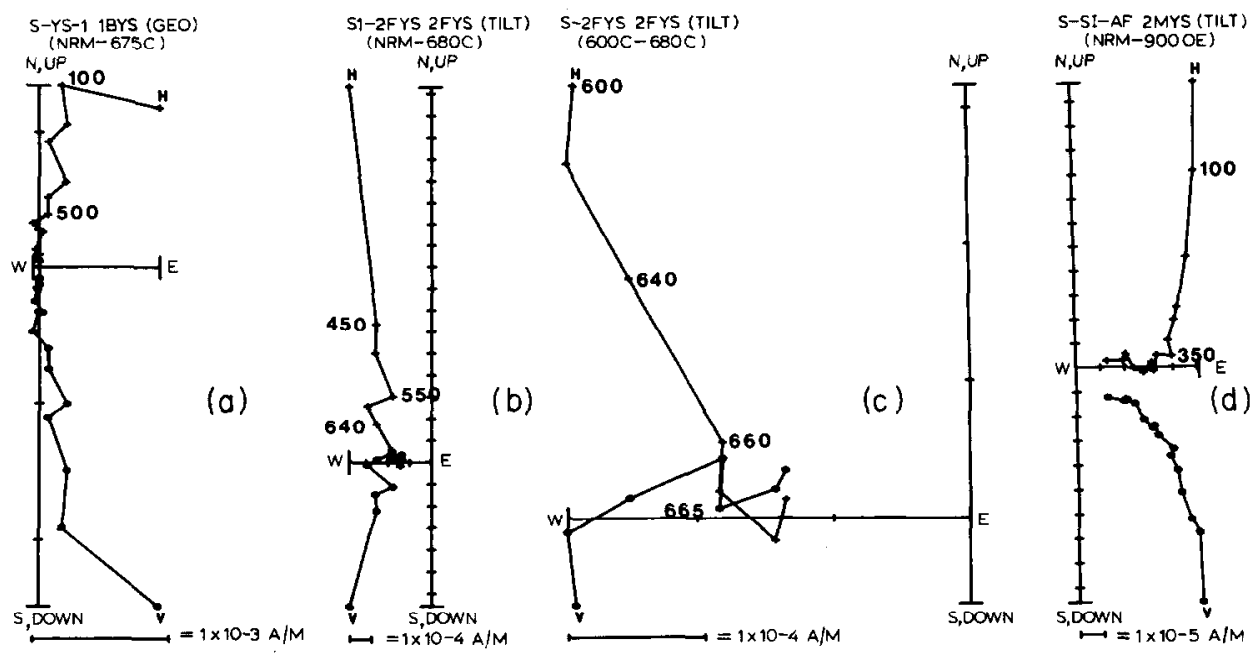

Fig. 7. Orthogonal projections of three samples from Quijing Section Yunnan. c. Same sample as (b) with directions plotted above $600^{\circ} \mathrm{C}$ so that high temperature behavior may be seen. Plot (d) is behavior of one limestone sample to a.f. fields.

$600^{\circ} \mathrm{C}$ ) is illustrated in Fig. $7 \mathrm{c}$, so that it can be more clearly seen.

Five of the sites sampled in this area were taken from nodular limestone near the proposed boundary between the Silurian and Devonian. In general, it was not possible to isolate a high coercivity, high blocking temperature component from these samples. However, in one case as shown in Fig. 7d, such a component was isolated. We were unable to replicate this result from other samples from the site. However, these data, as scant as they are, indicate that these sediments probably possess normal polarity, opposed to the direction isolated in Fig. 7c.

Site means for the two sites from which high temperature characteristic directions could be isolated are presented in Table 1 along with the results from the other localities.

\section{Discussion}

An overall pole position for the Silurian of the Yangtze platform has been calculated using the site means from each locality deemed to be reliable (15 accepted, 25 rejected). The pole, thus determined, falls at $4.9^{\circ} \mathrm{N}$ lat. and $194.7^{\circ} \mathrm{E}$ long., $\alpha_{95}=5.6^{\circ}$. A pole at this position places the South China block in low paleolatitudes (about $7^{\circ} \mathrm{N}$ or $\mathrm{S})$ at the time these rocks were magnetized.

It is difficult to place securely the date of this magnetization; however, it should be pointed out that the direction of magnetization is certainly prefolding so it is certain to be older than the Cretaceous. The pole position is similar to no other reported pole position from the later Paleozoic or Mesozoic rocks from the South China Block. It does fall, however, close to the pole reported from Cambrian rocks by Lin et al. (1985; Fig. 8). The meaning of the similarity of these two pole positions is not clear at this time; however, a later remagnetization of the Cambrian rocks in the middle Paleozoic cannot be discounted. Since we have concordant directions from different localities with two polarities, it seems reasonable to

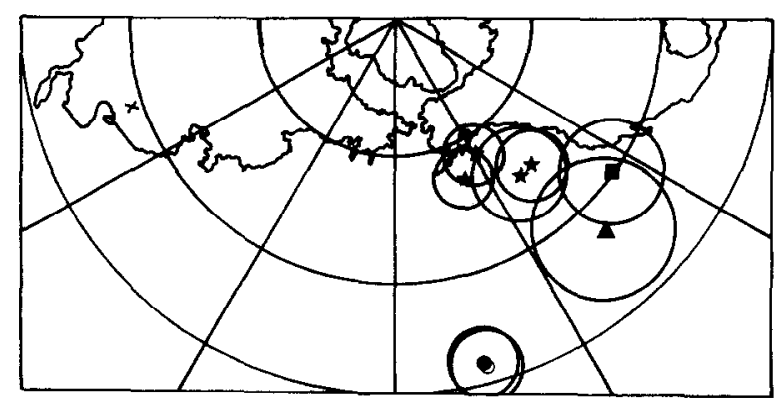

Fig. 8. Pole positions from the Paleozoic and Lower Mesozoic of the South China Block. Stars represent Triassic pole positions Opdyke et al. (1986), filled square-Permian; triangle-Carboniferous; open circle-Cambrian, all after Lin (1985), filled circle represents the Silurian pole from this study. The sampling region in China is indicated by the cross. 
presume that the direction observed is representative of the Silurian paleofield.

Recently an analysis of Silurian and Devonian biogeography based on shallow marine invertebrate faunas has been provided by $\mathrm{Yu}$ et al. (1984). They conclude that the faunas of the South China block are largely endemic for the Silurian. It seems probable, therefore, that the Yangtze Craton in the Silurian was not adjacent to or part of a larger continental plate. In the Silurian it would seem that it was isolated in low latitudes and would probably remain so until the Mesozoic.

\section{Acknowledgments}

The authors wish to thank all those in China who made this study possible. This work was supported by N.S.F. grants to L.D.G.O., and the University of Florida. L.D.G.O. contribution No. 4147.

\section{References}

Fisher, R.A., 1953. Dispersion on a sphere. Proc. R. Soc. London, Ser. A, 217: 295-305.

Kirschvink, J., 1980. The least-squares line and plane and the analysis of paleomagnetic data. Geophys. J. R. Astron. Soc., 62: 699-718.

Lin, B., Guo, D. and Wang, X., 1982. The Silurian system of China. In: An Outline of the Stratigraphy of China (edited by the Chinese Academy of Geological Sciences). Geological Publishing House, Beijing.

Lin, J.L., 1984. Apparent polar wander paths for the North and South China blocks. Thesis, Univ. of California, Santa Barbara, Calif.

Lin, J., Fuller M. and Zhang, W.Y., 1985. Apparent polar wander paths for the North and South China blocks. Nature, 313: 444-449.

McElhinney, M.W., 1964. Statistical significance of the fold test in Paleomagnetism. Geophys. J. R. Astron. Soc., 8: 338-340.

Mu, E., Chen, X., Ni, Y. and Rong, J., 1982. On the division and correlation of the Silurian system of China. In: The Correlation Tables of the Chinese Strata of Various Periods and Their Explanation (edited by the Nanjing Institute of Geology and Paleontology, Academia Sinica). Scientific Publishing House, Beijing.

Opdyke, N.D., Huang, K., Xu, G., Zhang, W.Y. and Kent, D.V., 1986. Paleomagnetic results from the Triassic of the Yangtze Platform. J. Geophys. Res., 91: 9553-9568.

Yu. W., Boucot, A.J., Rong, J-Y. and Yang, X, 1984. Silurian and Devonian Biogeography of China. Geol. Soc. Am. Bull., 95 (3): 265-279.

Zhang, Zh.M., Liou, J.G. and Coleman, K.G., 1984. An outline of the plate tectonics of China. Geol. Soc. Am. Bull., 95 (3): 295-312. 